\title{
The Practices of Republic Indonesia's Diplomacy to Taking Over The Management of Flight Information Region (FIR) above Natuna Island From The Republic of Singapore
}

\author{
Pramono Benyamin \\ Faculty of Communication Science \\ Padjadjaran University \\ Bandung, Indonesia \\ benyaminpramono@yahoo.com
}

\begin{abstract}
Indonesia has to fully control "Flight Information Region" (FIR) over the Natuna islands to strengthen control over air space in the border area. Natuna borders on South China Sea in which Pacific big powers, China and the United States have security interest. FIR over Natuna has to be put immediately under full control of Indonesia. FIR concerns not only flight safety, but also the country's sovereignty," Bamsoet said during a working visit to the border area together with the country's military chief, FIR over Natuna is still controlled by Singapore. Currently the government puts border areas high in priority in its development program. The paradigm of development in border areas should be based on national security and improvement of the local people's welfare, Indonesia's territorial security is determined partly by security in border areas. Therefore, development of military base in the Natuna islands is very important. It is not impossible we also would build and strengthen military bases in other outermost islands.
\end{abstract}

Keywords- millitary support; national defence; taking over airspace.

\section{INTRODUCTION}

FIR (flight information region) is a part of regulation of aviation and aviation problem areas infinitely at one state, which means that aviation world would be touching by one and another states, then to achieved safety on aviation regulation is necessary. Flight information region is an air space regulation that flight information service and alerting service are contained in. FIR's dispute starts with RAN I that hold by ICAO. On RAN I's meeting said that FIR management in Natuna Islands has been delegated to Singapore because Indonesia couldn't have ability to manage this FIR effectively. Because of technology and human resources restrictiveness. There's so many phenomenon that makes Indonesia want to take back Indonesia's authority on FIR with any efforts [1].

This research theoretically has built with realism perspectives on International Relations and supported by Diplomacy Theory by Harold Nicholson with setting diplomacy and also state analysis [2]. Formulation of all arguments, facts and theoretical framework on this research is guided by qualitative explanation methods. Scope of this research is Singapore's management on FIR and also Indonesia's diplomacy to taking back FIR from Singapore.

\section{RESUlts AND Discussion}

Researcher has formulated an answered-hypothesis that Indonesia's diplomacy with joint management model to finish this FIR dispute in Natuna Islands with Singapore. Joint management is made to finish this dispute because Indonesia want to make a peace and win-win solution. So joint management diplomacy is used to finish this FIR dispute currently [3].

In aviation, a flight information region (FIR) is a specified region of airspace in which a flight information service and an alerting service (ALRS) are provided. It is the largest regular division of airspace in use in the world today. FIRs have existed since 1947 at least. Every portion of the atmosphere belongs to a specific FIR. Smaller countries' airspace is encompassed by a single FIR; larger countries' airspace is subdivided into a number of regional FIRs.

Some FIRs encompass the territorial airspace of several countries. Oceanic airspace is divided into Oceanic Information Regions and delegated to a controlling authority bordering that region. The division among authorities is done by international agreement through the International Civil Aviation Organization (ICAO) [4][5].

There is no standard size for FIRs - it is a matter for administrative convenience of the country concerned. In some cases there is a vertical division of the FIR, in which case the lower portion remains named as such, whereas the airspace above is named Upper Information Region (UIR).

An information service and alerting service are the basic levels of air traffic service, providing information pertinent to the safe and efficient conduct of flights and alerting the different relevant authorities should an aircraft be in distress. These are available to all aircraft through a FIR [6][7]. Higher 
levels of Air Traffic Advisory and Control services may be available within certain portions of airspace within a FIR, according to the ICAO class of that portion of airspace (with regard to national regulations), and the existence of a suitably equipped authority to provide the services.

In a sovereign form or conception of the state requires understanding and awareness of each individual about the sovereignty of his country. Such awareness includes awareness of space and boundary consciousness that will form the conception of space (space conception) of a nation about the territory of the country. If it is not handled seriously, the question of a country's borders will still be a great homework for any government.

As President of the Republic of Indonesia Susilo Bambang Yudhoyono during his reign at that time has made a lot of efforts to take over FIR from the power of Singapore. As we have seen that the thing that also makes Indonesia inferior under Singapore is the fact that we are actually not fully sovereign over the air of our own country as some are still controlled by Singapore.

Until 2014 the end of the administration of President Susilo Bambang Yudhoyono part of Indonesia's airspace will still be controlled by Singapore's air traffic controllers. Why this can happen, because that is the sound of Presidential Decree No. 7/1996 on the ratification of the FIR (Flight Information Region) agreement with Singapore, which states that the eastern navigation system in Indonesia is controlled by Singapore no later than 15 years [8].

In the Law of the Republic of Indonesia No. 3 of 2002 on State Defense stated that the defense of the state aims to safeguard and protect the sovereignty of the state, the territorial integrity of the Unitary State of the Republic of Indonesia (NKRI) and the safety of the whole nation from all forms of threat. Efforts to realize the recognition of sovereignty in the territorial waters of the archipelago are inseparable from the archipelago principles of the four countries' (Fiji, Filipina, Indonesia, Mauritius) disclosure documents at the session of the United Nations Seabed Committee in 1972 in New York, particularly the second principle which states, "The archipelagic sovereign state of the waters contained in the straight line is drawn between the outer islands of the island. This sovereignty not only covers the waters but includes seabed and subsoil and airspace over archipelagic waters [9].

Conception of space referred to Friedrich Ratzel certainly also related to the problem of state sovereignty in the air. In the aviation world there is a Flight Information Region (FIR) whose territory is not based on territorial territory, but based on safety consideration. In connection with the issue of state sovereignty in the air, the control of Air Traffic Control (ATC) by Singapore in the Indonesian territory of Riau Islands (Kepri), not only causes violations of the territorial sovereignty of the Unitary State of the Republic of Indonesia (NKRI) which is very broad especially in aspects of air defense and economic losses.

The management of air navigation, especially in the west, is not $100 \%$ controlled by Indonesia. The management of the $\mathrm{ABC}$ sector airspace or in the Riau Islands area, Natuna, is still controlled by the Singapore authorities. Because the Flight Information Region (FIR) system is still held by the Air Traffic Control tower of Singapore so that Indonesian aircraft flying in the area must be licensed to Singapore even though flying over the territory of Indonesia. It turned out that surveillance and regulation of FIR for Natuna or ABC sectors has been held by Singapore since 1946 or one year after Indonesia became independent. At that time, the International Civil Aviation Organization (ICAO) held a meeting to discuss the distribution and management of FIR. But the Indonesian representatives were not present. As a result, the FIR for Natuna area is given to Singapore.

\section{CONCLUSION}

This condition is quite alarming because foreign aircraft are free to pass without any supervision by FIR (Flight Information Region) Indonesia located in Jakarta. This concern not only arises from Indonesia but also from the country around it as Indonesia's fragility means a threat to them. Indonesia's unstable condition makes the country around to try to take action especially in the case of Indonesia's air safety that tend to be neglected, FIR (Flight Information Region) is a specified airspace of its dimensions in which provided Flight Information Service and Alerting Service.

\section{REFERENCES}

[1] GFN-SSR, A Beginner's Guide to Security Sector Reform (SSR). United Kingdom : GFN-SSR, 2007.

[2] OECD. DAC Guidelines and Reference Series : Security System Reform and Governance. OECD Publishing, 2005.

[3] United Kingdom, Defence Diplomacy, Ministry of Defence Policy Paper No. 1

[4] http://www.recaap.org/Home.aspx

[5] http://www.deplu.go.id/moscow/Pages/Divisions.aspx?IDP=8\&l=id

[6] http://maritime-connector.com/ship/crest-gold-1-9468267/

[7] http://americansecurityproject.org/issues/climate-energyandsecurity/energy/todays-supply/geographic-choke-points/

[8] http://www.shipspotting.com/gallery/photo.php?lid=1466288

[9] http://www.deplu.go.id/Daftar\%20Perjanjian\%20Internasional/singapura .htm 